\title{
eHealth in Public Health Services
}

\author{
Prof. Vajira H. W. Dissanayake MBBS, PhD \\ Executive Editor, Sri Lanka Journal of Bio-medical Informatics \\ E-mail address: vajirahwd@hotmail.com
}

Sri Lanka Journal of Bio-Medical Informatics 2012;3:32-33

doi: http://dx.doi.org/10.4038/sljbmi.v3i2.5224

At the $58^{\text {th }}$ World Health Assembly, the World Health Organisation, Stressing that eHealth is the cost-effective and secure use of information and communications technologies in support of health and health-related fields, including health-care services, health surveillance, health literature, and health education, knowledge and research urged the member states to consider establishing and implementing national electronic public-health information systems and to improve, by means of information, the capacity for surveillance of, and rapid response to, disease and public-health emergencies ${ }^{(1)}$.

In this issue of the Journal several papers highlight how eHealth solutions have been used in the public health sector in Sri Lanka. The leading article deals with the successful

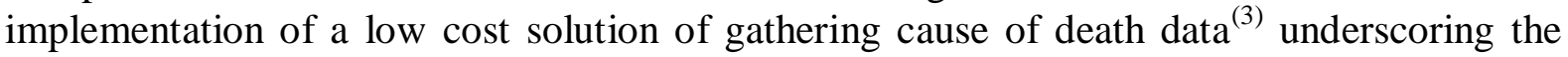
importance of simple but practical solutions. Two case reports of pilot implementations of simple eHealth solution to overcome the data gathering and reporting problems faced by public health midwives highlight the fact that implementation of eHealth solutions at field level is feasible in Sri Lanka ${ }^{(3,4)}$. In addition to these a current practice article reviews how information and communication technology can be used in the fields of human resources management in public health services ${ }^{(5)}$.

We hope that such initiatives would become widespread in the health sector in Sri Lanka in the years to come and that we would reap the benefits the availability of real time data to help decision making in the health sector in Sri Lanka.

\section{References}

1. World Health Organisation. A Resolution on eHealth adopted at the $58^{\text {th }}$ World Health Assembly. Available at http://www.who.int/healthacademy/news/en/index.html. Accessed on 31 March 2012.

2. Rampatige R, Abusayeed MH. Low cost health Information Technology to improve the quality of cause of death certification data. Sri Lanka Journal of Bio-Medical Informatics 2012;3: 34-39

doi: http://dx.doi.org/10.4038/sljbmi.v3i2.3567

3. Rodrigo ESS, Wimalarathne SRU, Marasinghe RB, Ediripullige S. "e-Praja Suwa Arunalu": A Pilot Study of a Health Information Management System for Public Health Midwives in Sri Lanka. Sri Lanka Journal of Bio-Medical Informatics 2012;3: 40-46 doi: http://dx.doi.org/10.4038/sljbmi.v3i2.4737

4. Manoj S. Customising DHIS2 for Maternal and Child Health Information Management in Sri Lanka. Sri Lanka Journal of Bio-Medical Informatics 2012;3: 47-54

doi: http://dx.doi.org/10.4038/sljbmi.v3i2.2496 
5. Mujeeb LM. Importance of best Human Resource Management Practices and the need for a Human Resource Information System (HRIS) for the Public Health Sector in Sri Lanka. Sri Lanka Journal of Bio-Medical Informatics 2012;3: 55-62 doi: http://dx.doi.org/10.4038/sljbmi.v3i2.2449 